\title{
PENEGAKAN HUKUM PEMANFAATAN TANAH KAWASAN HUTAN DI KABUPATEN LOMBOK TIMUR
}

\author{
LAW ENFORCEMENT ON LAND OF FOREST AREA \\ UTILIZATION IN EAST LOMBOK REGENCY
}

\author{
Sahnan \\ Fakultas Hukum Universitas Mataram \\ Email : sahnan_mih@yahoo.co.id \\ Zainal Asikin \\ Magister Ilmu Hukum Universitas Mataram \\ Email : asikinzainal@yahoo.com
}

Naskah diterima : 25/01/2018; direvisi : 27/03/2018; disetujui : 27/04/2018

\begin{abstract}
This research has purposes to discovered and analyzed the implementation of law enforcement against forest possession or forest occupation in Jarang Koak sub village, Bebidas Village, Wanasaba District, West Lombok regency. This research purposes also to analyze the obstacles that the officials faced in an implementation of law enforcement in the forest possessions. The results of this study are (1) The implementation of the law enforcement on land use forest in Jurang Koak sub village, Bebides Village, Wanasaba District, East Lombok Regency is not working properly. The problem in this situation is the law enforcement officials only see the law enforcement from legal certainty perspectives, they ignored the principle of utilizing and the principle of justice in laws. This three aspects in law must be implemented even though the implementation of this three aspects in reality is not easy. (2) The obstacles of the law officials faced in the implementations of law enforcement in a land forest can be divided in three element, that is: structures, substances, and cultures of law.
\end{abstract}

\section{Keywords: Law Enforcement, Land Uses In Forestry.}

\begin{abstract}
Abstrak
Penelitian ini bertujuan untuk mengkaji dan menganalisis pelaksanaan penegakan hukum penguasaan dan pemilikan tanah kawasan hutan di Dusun Jarang Koak, Desa Bebidas, Kecamatan Wanasaba, Kabupaten Lombok Timur. Mengkaji dan menganalisis kendala-kendala yang dihadapi dalam penegakan hukum pemanfaatan tanah kawasan hutan tersebut. Dari Hasil Penelitian dapat di kemukakan bahwa (1) dalam Pelaksanaan penegakan hukum dalam pemanfaatan tanah kawasan hutan di Dusun Jurang Koak, Desa Bebidas, Kecamatan Wanasaba, Kabupaten Lombok Timur masih belum berjalan sebagaimana yang diharapkan. di mana para aparat penegak hukum dalam penegakan hukum, hanya melihat dari unsur kepastian hukumnya saja, dan mengabaikan unsur manfaat dan keadilannya. Pada hal ketiga unsur tersebut harus mampu diterapkan secara bersamaan, kalaupun pelaksanaan dari ketiga unsur tersebut di dalam praktiknya tidaklah mudah. Sedangkan (2) Kendala-kendala yang di hadapi dalam penegakan hukum pemanfaatan tanah kawasan hutan dapat di bagi menjadi tiga yakni: dari sisi struktur, substansi dan kultur.
\end{abstract}

\section{Keywoords: Penegakan Hukum, Tanah Kawasan Hutan.}




\section{PENDAHULUAN}

Indonesia sebagai negara agraris, dimana tanah sangat menentukan kelangsungan hidup rakyatnya. Hal ini terlihat dalam Pasal 33 ayat (3) UndangUndang Dasar 1945 yang berbunyi :

"Bumi, air, dan ruang angkasa ser-

ta kekayaan alam yang terkandung didalamnya dikuasai oleh negara dan diperuntukan sebesar-besarnya kemakmuran rakyat".

Untuk mengimplimentasikan pasal di atas, maka lahirnya Undang-Undang No. 5 Tahun 1960 Tentang Peraturan DasarDasar Pokok Agraria, sebagai landasan untuk pengaturan pemanfaatan sumber daya alam khususnya tanah. Pemanfaatan tanah untuk sebesar-besarnya kemakmuran rakyat merupakan "conditio sine quanon". Guna mencapai tujuan ini diperlukan campur tangan pemerintah sebagaimana yang ditegaskan dalam Pasal 33 ayat (3) UUD 1945 yaitu "tanah dikuasai oleh negara dan dipergunakan untuk sebesar-besarnya kemakmuran rakyat secara adil dan merata".

Manusia tidak bisa terlepas dari tanah, karena manusia berasal dari sari pati tanah, dan hidup dari tanah, dan matipun manusia membutuhkan tanah sebagai tempat pemakamannya. Jumlah manusia semakin bertabah, kebutuhan akan tanah semakin bertambah, sedangkan luas tanah terbatas. Sehingga tidak mengherankan perebutan sumber daya tanah terus meningkateskalasinya, sampai terjadi korban jiwa. Apalagi dikaitkan dengan pelaksanaan pembangunan yang semakin menggeliat menyebabkan tanah memiliki nilai ekonomis yang tinggi, dan nilainya akan terus mengalami peningkatan. ${ }^{2}$

\footnotetext{
${ }^{1}$ Undang-Undang Dasar Republik Indonesia 1945 beserta perubahannya susunan kabinet RI lengkap (1945-2014) profil kabinet Indonesia bersatu jilid II dan Lembaga Tinggi Negara.

2 Achmad Chulaemi, "Pengadaan Tanah Untuk Keperluan Tertentu Dalam Rangka Pembangunan", Majalah Masalah-Masalah Hukum, Nomor
}

Dengan demikian, yang penting memperoleh perhatian tidak hanya permasalahan distribusi (penetapan) pemanfaatan tanah pada umumnya, akan tetapi bagaimana pemanfaatan tanah kawasan hutan yang justru semakin merebak dewasa ini, dan tidak jarang menimbulkan konflik atau sengketa. Permasalahan sengketa penguasaan atau pemilikan tanah kawasan hutan antara pemerintah (yang menyebut dirinya negara) dengan masyarakat pada umumnya dan masyarakat hukum adat pada khususnya, sebenarnya tidak hanya muncul di era reformasi ini, akan tetapi sudah muncul jauh sebelumnya. Sebenarnya konflik atau sengketa terus mengalami peningkatan dari masa ke masa dan eskalasinya mengalami peningkatan seiring bergulirnya reformasi dengan berbagai eksesnya. ${ }^{3}$

Sementara itu di dalam UndangUndang Nomor 41 Tahun 1999 Pasal 50 ayat (3) hurup a telah menentukan bahwa setiap orang dilarang mengerjakan dan atau menggunakan dan atau menduduki kawasan hutang secara tidak sah. Kemudian lebih lanjut ketentuan pasal di atas, dalam penjelasannya di kemukakan bahwayang dimaksuddengan mengerjakan kawasan hutan adalah mengolah tanah dalam kawasan hutan tanpa mendapat izin dari pejabat yang berwenang, antara lain untuk perladangan, untuk pertanian, atau untuk usaha lainnya; Yang dimaksud dengan menggunakan kawasan hutan adalah memanfaatkan kawasan hutan tanpa mendapat izin dari pejabat yang berwenang, antara lain untuk wisata, penggembalaan, perkemahan, atau penggunaan kawasan hutan yang tidak sesuai dengan izin yang diberikan; dan yang dimaksud dengan menduduki kawasan hutan adalah menguasai

\footnotetext{
1, Fakultas Hukum, Universitas Dipoenegoro, Semarang 1992, hlm. 9

${ }^{3}$ Bambang Eko Supriyadi, Hukum Agraria Kehutanan (Aspek Hukum Pertanahan Dalam Pengelolaan Hutan Negara), Raja Grafindo, Jakarta, 2013, hlm. 2.
} 
Sahnan \& Zainal Asikin|Penegakan Hukum Pemanfaatan Tanah Kawasan Hutan di Kabupaten..

kawasan hutan tanpa mendapat izin dari pejabat yang berwenang, antara lain untuk membangun tempat pemukiman, gedung, dan bangunan lainnya. ${ }^{4}$

Pelarangan dan penegakan hukum terhadap penguasaan dan pengklaiman pemilikan hak atas tanah bagi setiap orang terhadap tanah kawasan hutan perlu dilakukan. Hal ini dimaksudkan agar warga masyarakat tidak sewenangwenang masuk atau menduduki atau menguasai tanah kawasan hutan untuk dimanfaatkan. Karena jika pemerintah tidak tegas untuk melakukan tindakan maka akan menjadi preseden buruk dalam penegakan hukum, seperti yang terjadi di kabupaten Lombok timur khususnya Dusun Jurang Koak, Desa Bebidas, Kecamatan Wanasaba. Penguasaan atau pengklaiman tanah kawasan hutan negara oleh warga masyarakat perlu dilakukan penegakan hukum, hal ini dimaksudkan agar jangan sampai kawasan hutan diduduki atau di kuasai secara tidak sah oleh warga masyarakat.

Penegakan hukum oleh Pengelola Taman Nasional Gunung Rinjani terhadap warga masyarakat yang mengklaim atau menguasai tanah kawasan hutan yang menurut persepsinya mereka telah dikuasai secara turun temurun, namun dengan berbatasannya tanah kawasan hutan yang dikuasai oleh warga masyarakat Jurang Koak ini dengan Taman Nasional Gunung Rinjani, maka terjadilah sengketa antara kedua belah pihak, dengan bebrapa alasan diantaranya, bahwa pihak pengelola Taman Nasional Gunung Rinjani mengatakan bahwa tidak ada batas yang pasti antara taman nasional gunung rinjani dengan tanah kawasan hutan yang dikuasai oleh warga masyarakat.

${ }^{4}$ Sahnan et.al, Sengketa Pemanfaatan Tanah Kawasan Hutan Antara Warga Masyarakat Dengan Dinas Kehutanan (Studi Kasus Tanah Kawasan Hutan Pelangan, Desa Kedaro, Kec. Sekotong, Kab. LombokBarat, NTB, 2016, hlm. 3
Hutan adat yang memiliki luas 374 hektar ini sebagian besar digunakan oleh masyarakat yang bermukim di sekitarnya untuk bertani. Beraneka jenis sayuran yang ada di lahan tersebut seperti: tomat, cabai, wortel, kol, dan yang paling banyak adalah bawang merah dan bawang putih. Disamping itu juga, sebagian masyarakat memanfaatkan hutan tersebut untuk mencari kayu bakar dan sebagainya.

Kenyataan sepintasini, memperlihatkan kondisi realistik mengenai pengaturan dan penegakan Hukum masih terus dilakukan pembenahan.Berdasarkan latar belakang tersebut, penelitian ini hendak mengkaji pelaksanaan penegakan hukum pemanfaatan tanah kawasan hutan di Dusun Jurang Koak, Desa Bebidas, Kecamatan Wanasaba, Kabupaten Lombok Timurdan Faktor-faktor apa saja yang menjadi kendala dalam penegakan hukum pemanfaatan tanah kawasan hutan di Dusun Jurang Koak, Desa Bebidas, Kecamatan Wanasaba, Kabupaten Lombok Timur.Penelitian ini merupakan penelitian hukum normatifemperis yaitu penelitian hukum yang mengkaji asas/prinsip keadilan hukum, sebagai perwujudan nilai-nilai tertentu, ${ }^{5}$ dalam hal ini mengkaji norma-norma dan konsep-konsep hukum yang mengatur tentang kawasan hutan dan penegakan hukum, selain itu juga melihat bagaimana pelaksanaan hukum di lapangan. Kemudian metode pendekatan yang digunakan dalam penelitian ini adalah yaitu: pendekatan perundang-undangan, pendekatan kasus, pendekatan analitis, pendekatan historis, dan pendekatan sosiologis. Sumber bahan hukum yaitu dari sumber kepustakaan yang terdiri dari bahan hukum primer, bahan hukum

\footnotetext{
${ }^{5}$ M. Yazid Fathoni, "Konsep Keadilan Dalam Pengelolaan dan Pemanfaatan Sumber Daya Alam Menurut Undang-Undang Pokok Agraria Tahun 1960", Jurnal IUS (Hukum dan Keadilan), Vol. I, No. 1, April 2013, http://jurnalius.ac.id/ojs/index.php/jurnalIUS/article/ view/225/197, diakses tanggal 6 Desember 2017, hlm. 46
} 
sekunder, dan bahan hukum tersier. Teknik pengumpulan data dengan cara wawancara, dan teknik pengumpulan bahan hukum adalah studi dokumentasi. dan analisis bahan hukum dilakukan secara deskriptif kualitatif dan selanjutnya di tarik suatu kesimpulan secara deduktif.

\section{PEMBAHASAN}

Pelaksanaan penegakan hukum pemanfaatan tanah kawasan hutan Taman Nasional Gunung Rinjani di Dusun Jurang Koak, Desa Bebidas, Kecamatan Wanasaba, Kabupaten Lombok Timur.

Munculnya masalah pemanfaatan tanah kawasan hutan Taman Nasional Gunung Rinjani bermula dari sejak tahun 1929, dimana Taman Nasional Gunung ditetapkan sebagai hutan tutupan dengan surat keputusan Nomor 1-Sub I yang terbit tahun 1929. Kemudian ditetapkan menjadi kawasan suaka marga satwa melalui Keputusan Gubernur Hindia Belanda Nomor 15 . STBL Nomor 77 tanggal 17 Maret 1941 kemudian berkembang menjadi kawasan TNGR seluas 41.330 Hektar yang penetapannya melalui SK Menteri Kehutanan Nomor 280/KPTS -IV/1997.

Semenjak pemerintah menetapkan Kawasan hutan Gunung Rinjni menjadi kawasan suaka margasatwa yang sekarang menjadiTNGR.Inilahawalmulaterjadinya konflik antara warga masyarakat Dusun Jurang Koak Desa Bebidas Kecamatan Wanasaba Lombok timur dengan pihak pemerintah (Pengelola Taman Nasional Gunung Rinjani). Konflik tersebut muncul ke permukaan menjadi konflik terbuka di perkirakan berlangsung 5 (lima) kali yang bermula sejak tahun 1970-an.

Dari tahun 1970 sampai tahun 1980an warga masyarakat Dusun Jurang Koak dipimpin oleh Haji Mansur, kemudian pada tahun 1988 perjuangan warga masyarakat Dusun Jurang Koak di pimpinan oleh Roh Parman, dan kemudian dari tahun 1990-
2015 sampai sekarang di Pimpinan Amaq Sarsanah dan Amaq Jalan. Seorang aktifis Agra NTB, Samboeza Huriya mengatakan dari hasil diskusi bersama warga setempat, sudah sebanyak 32 warga Jurang Koak yang diseret ke meja hijau atas tuduhan melakukan aktifitas berladang atau mencari kayu di kawasan TNGR. "jumlah tersebut hanya dari Dusun Jurang Koak saja, belum termasuk Dusun Dasan Erot dan Gurne,". 6

Puncak konflik atau sengketa antara warga masyarakat Dusun Jurang Koak dengan Pemerintah (Pengelola TNGR) pada tahun 2015, ketika warga Masyarakat Jurang Koak secara bersama-sama memasuki tanah kawasan Taman Nasional Gunung Rinjani. Warga Masyarakat membuka lahan seluas 75 hektar dan masing-masing kepala keluarga mendapat 10-11 are saat ini warga masyarakat yang menggarap lahan tersebut sebanyak 650 Kepala Keluarga yang berasal dari Dusun Jurang Koak, Burne, Dasan Erot. Sampai saat ini, sejak dibuka tahun lalu, masyarakat sudah melakukan penanaman 3 (tiga) kali musim tanam dengan penghasilannya dapat untuk memenuhi kebutuhan hidup sehari-hari mereka.

Meminjam pandangan Laura Nadder dan Todd, munculkeluhan dari masyarakat yang tidak menerima kawasan tersebut untuk ditetapkan menjadi kawasan Suaka Margasatwa atau sekarang menjadi Kawasan Taman Nasional Gunung Rinjani, karena warga masyarakat tidak lagi mendapatkan akses untuk memenuhi kebutuhan hidupnya di kawasan Taman Nasional Gunung Rinjani. Masyarakat dilarang untuk memasuki kawasan hutan secara sembarangan, memungut hasil hutan atau menggarap tanah kawasan

${ }^{6}$ Risdiana, Perlindungan Hukum Hak Atas Tanah Hutan yang Dikelola Masyarakat Adat Dalam Kawasan Hutan Tamanan Nasional Gunung Rinjani, Dusun Jurang Koak, Desa Bebidas, Kecamatan Wanasaba, Kabupaten Lombok Timur,Program Magister Ilmu Hukum, Program Pascasarjana, Universitas Mataram, 2017. hlm 56 
Sahnan \& Zainal Asikin|Penegakan Hukum Pemanfaatan Tanah Kawasan Hutan di Kabupaten..

hutan. Semua larangan dari Pengelola Taman Nasional Gunung Rinjani tersebut tidak diindahkan oleh warga masyarakat Warga masyarakat tetap bersikukuh untuk memasuki secara paksa dan melakukan pendudukan bahkan membagikan tanahtanah tersebut. Pada tahap pertama ini disebut dengan pra konflik.

Melihat hal tersebut, maka terhadap kasus Taman Nasional Gunung Rinjani meningkat eskalasinya menjadi Konflik di kala pihak pengelola TNGR melakukan operasi gabungan dengan melakukan pengusiran secara paksa kepada warga masyarakat yang menduduki tanah kawasan hutan TNGR Secara tidak sah. Akan tetapi, langkah-langkah tersebut selalu mendapat perlawanan dari warga masyarakat, sehingga dicoba penyelesaian secara baik-baik atau dengan cara penyelesaian secara musyawarah mufakat atau negosiasi, namun tidak berhasil. Tahap kedua ini disebut dengan konflik.

Pada tahap ketiga, sudah meningkat eskalasinya menjadi sengketa, ketika konflik tersebut antara warga masyarakat dengan pihak Pengelola Taman Nasional Gunung Rinjani, kemudian telah muncul ke permukaan publik atau telah melibatkan pihak ketiga dalam proses penyelesaiannya. Dengan meningkat eskalasinya menjadi sengketa antara warga masyarakat Jurang Koak dengan pihak Pengelola TNGR,dimana pihak TNGR melakukan langkah hukum atau penegakan hukum dengan melaporkan tindakan-tindakan yang dilakukan oleh warga masyarakat yang tidak mau mengindahkan larangan-larangan untuk menduduki tanah kawasan hutan secara tidak sah kepada pihak yang berwajib dalam hal ini POLDA NTB.

Penegakan hukum yang dilakukan oleh pihak pengelola Taman Nasional Gunung Rinjani, yaitu dengan melaporkan kepada pihak yang berwajib untuk melakukan tindakan tegas sesuai dengan peraturan perundang-undangan yang berlaku.
Akhirnya 4 (empat) warga masyarakat petani Jurang Koak atas tuduhan membuat akses jalan di dalam kawasan hutan Taman Nasional Gunung Rinjani dengan menggunakan alat berat berupa Excavator Merk Hyundai PC 210-7 warna kuning kode urut 12 yang di sewa oleh Edi Putra Alias Amaq Dewi di perusahaan PT. Pramana Artha Raharja di tangkap. ${ }^{7}$

Pada hari rabu tanggal 25 mei 2016 dini hari, Kepolisian Daerah (POLDA) NTB, menangkap dan menjemput secara paksa seorang warga masyarakat yang bernama Rusmin Nuryadin alias Amaq Wir ${ }^{8}$ di rumahnya. Selanjutnya menyusul 2 (dua) orang di tankap pada Hari Rabu Tanggal 8 Juni 2016 yakni: Sapi'i alias Amaq Nopi ${ }^{9}$ dan Sulaiman alias Amaq Nanda ${ }^{10}$. Pada waktu penangkapan warga masyarakat yakni Amaq Nopi dan Amaq Nanda oleh aparat polda NTB dan petugas TNGR dengan menggunakan senjata lengkap dan juga gas airmata, 3 unit mobil dengan kurang lebih 30 personel. Menurut cerita warga masyarakat penggerebekan yang dilakukan oleh warga masyarakat terhadap 2 pejuang tanah adat tersebut, tanpa basa-basi puluhan aparat langsung mengeluarkan puluhan tembakan ke arah atap rumah Amak Nopi, sehingga menyebabkan atap rumahnya bolong, selanjutnya menciduk kedua pejuang tanah adat, melihat sikap kepolisian yang sangat berlebihan, Amaq Nopi sempat mempertayakan sikap kepolisian dengan mengatakan: "salah saya apa? Saya bukan teroris, saya bukan maling," akan tetapi langsung disambut gertakan keras dari aparat, pada saat Amak Nopi diborgol sontak ibu korban (50 tahun) yang melihat kejadian langsung bergerak ingin

\footnotetext{
7 Berkas Perkara Nomor: BP 03/V/BTNGR-1/ PPNS/2016, Kementrian Lingkungan Hidup dan Kehutanan Direktorat Jenderal Konservasi Sumber Daya Alam dan Ekosistem Balai Taman Nasional Gunung Rinjani. Koak.

Selaku ketua pejuang tanah adat Dusun Jurang

${ }^{9}$ Bendahara pejuang tanah adat Dusun Jurang Koak

${ }^{10}$ Sekretaris pejuang tanah adat Dusun Jurang Koak
} 
membantu anaknya, akan tetapi dihadang oleh aparat hingga terjatuh. Melihat hal tersebut Amaq Nopi bereaksi akan tetapi langsung dihadapkan dengan 5 personil yang melakukan pemukulan terhadapnya, kedua korban dipukuli hingga terjatuh dan diinjak oleh aparat, dan kedua korban diseret ke-dalam mobil. Melihat penangkapan yang berutal oleh aparat, masa langsung bereaksi menghadang dengan kayu dan melempar mobil yang membawa korban dengan batu, aparat keamanan membalas dengan tembakan dan gas airmata". ${ }^{11}$ Dan selanjutnya selain itu juga Amaq Dewi yang menyewa excavpator juga ditangkap.

Dalam Berita acara pemeriksaan disebutkan bahwa dengan adanya perambahan hutan di Taman Nasional Gunung Rinjani yang dilakukan oleh warga masyarakat telah menimbulkan kerugian atau berdampak sebagai berikut:

1. Akan mengganggu ekosistem Hutan;

2. Tidak lagi hutan dapat menyimpan air atau akan dapat menyebabkan terjadi erosi;

3. Hutan tidak lagi dapat memproduksi oksigen;

4. Dapat menyebabkan kerugian negara dari sisi ekonmi dengan adanya penebangan yang dilakukan secara tidak bertanggung jawab serta semakin sempitnyawilayahhutanakibatkegiatan perambahan. ${ }^{12}$

Dalam berkas perkara Nomor: BP. 03/V/BTNGR-1/PPNS/2016 menyatakan bahwa warga masyarakat tersebut "diduga telah melakukan tindak pidana di bidang kehutanan dan/atau di bidang konservasi sumberdaya alam hayati dan ekosistemnya yaitu melakukan kegiatan yang tidak sesuai dengan fungsi zona TNGR yang adapat mengakibatkan perubahan terhadap keutuhan kawasan

\footnotetext{
${ }^{11}$ Risdiana, Op.cit.

12 Berita Acara Pemeriksaan Saksi pada hari rabu tanggal 11 November tahun 2015 pukul 13 .00 Wita tempat di ruangan Unit I Subdit IV Dit Reskrimsus Polda NTB.
}

pelestarian alam dan/atau membawa alat berat dan/atau alat-alat lain yang lazim dan patut dipergunakan di kawasan perkebunan, di dalam kawasan hutan tanpa izin menteri mengangkut hasil kebun di kawasan hutan terjadi dalam kawasan TNGR... sebagaimana dimaksud dalam Pasal 40 ayat (2) jo Pasal 33 ayat (3) Undang-Undang RI Nomor 5 Tahun 1990 tentang Konservasi Sumberdaya Alam Hayati dan Ekosistem dan/atau Pasal 92 ayat (1) huruf b jo Pasal 17 ayat (2) huruf a Undang-Undang RI Nomor 18 Tahun 2013 tentang Pencegahan dan Pemberantasan Perusakan Hutan jo Pasal 55 ayat (1) ke 1 KUHPidana."

Konflik atau sengketa antara warga masyarakat dengan pemerintah (pengelola TNGR) terjadi semenjak pemerintah menetapkan kawasan tersebut sebagai kawasan hutan lindung atau TNGR. Karena menurut persepsi warga masyarakat bahwa tanah kawasan hutan yang ditetapkan sebagai kawasan TNGR adalah merupakan "kawasan Tanah Hutan Adat Jurang Koak yang merupakan tanah yang dikuasai secara turun temurun oleh para leluhur mereka dari sejak sebelum kemerdekaan. Menurut Anang Husni, keberadaan masyarakat Adat mendapat pengakuan dalam pengelolaan hutan oleh negara atau pemerintah, hal ini dapat di dijumpai dalam UU No. 41 tahun 1999 tentang kehutanan, terutama Pasal 67 ayat (1) yang menyatakan bahwa keberadaan masyarakat hukum adat dalam pengelolaan hutan diakui sepanjang memenuhi syarat-syarat sebagai berikut:

1. Masyarakat masih dalam bentuk paguyuban;

2. Ada kelembagaan dalam bentuk perangkat penguasa adatnya;

3. Ada wilayah hukum adat yang jelas;

4. Ada pranata dan perangkat hukum, khususnya peradilan adat yang masih ditaati; 
Sahnan \& Zainal Asikin|Penegakan Hukum Pemanfaatan Tanah Kawasan Hutan di Kabupaten..

5. Masih mengadakan pemungutan hutan di wilayah hutan sekitarnya untuk pemenuhan kehidupan sehari-hari; Memang, pada umumnya keberadaan masyarakat adat telah diatur didalam Pasal 3 Undang-Undang nomor 5 tahun 1960 tentang Peraturan Dasar PokokPokok Agraria yaitu sebagai berikut: "Dengan mengingat ketentuan-ketentuan Pasal 1 dan 2, pelaksanaan hak ulayat dan hak-hak yang serupa dari masyarakatmasyarakat hukum adat, sepanjang menurut kenyataannya masih ada, harus sedemikian rupa sehingga sesuai dengan kepentingan nasional dan Negara, yang berdasar atas persatuan bangsa serta tidak boleh bertentangan dengan undangundang dan peraturan-peraturan lain yang lebih tinggi".

Hak masyarakat hukum adat mengandung 2 (dua) unsur yaitu: ${ }^{13}$

1. Unsur kepunyaan yang termasuk dalam bidang hukum perdata;

2. Unsur tugas dan kewenangan untuk mengatur penguasaan dan memimpin penggunaan tanah bersama, yang termasuk bidang hukum publik yang pelaksanaannya dilimpahkan kepada Kepala Adat sendiri atau bersama-sama dengan para Tetua Adat masyarakat hukum adat yang bersangkutan.

Menurut Pasal 1 Peraturan Menteri Negara Agraria/Kepala Badan Pertanahan Nasional (Permen Agraria/Kepala BPN) Nomor 5 tahun 1999 tentang pedoman penyelesaian Masalah Hak Ulayat Masyarakat Hukum Adat, yang di maksud dengan Hak Ulayat adalah kewenangan yang menurut adat di punyai oleh masyarakat hukum adat tertentu atas wilayah tertentu yang merupakan lingkungan hidup para warganya untuk mengambil manfaat dari sumber daya alam (SDA), termasuk tanah dalam wilayah tersebut, bagi kelangsungan

\footnotetext{
${ }^{13}$ Budi Harsono, Hukum Agraria indonesia (Sejarah Pembentukan Undang-undang Pokok Agraria Indonesia, Isi dan Pelaksanaannya), Djambatan, Jakarta, $2005 \mathrm{hlm}$. 5. hlm. 271.
}

hidup dan kehidupannya, yang timbul dari hubungan secara lahiriah dan batiniah secara turun temurun dan tidak terputus antara Masyarakat Hukum Adat tertentu dengan wilayahnya.

Berdasarkan ketentuan di atas maka keberadaan warga masyarakat Jurang Koak yang mengklaim diri sebagai masyarakat adat sepatutnya dilakukan pengkajian terhadap keberadaan mereka, agar di dalam mengambil keputusan atau tindakan hukum yang dilakukan tidak bertentangan dengan prinsip-prinsip sebagaimana yang terkandung dalam Hak Asasi Manusia. Menurut $\mathrm{R}$ dan Warga Masyarakat Jurang Koak bahwa Aladin almarhum alias Balok Imah, Papuk Banun, Papuk Putrasih merupakan leluhur mereka yang semasa hidupnya tinggal di kawasan itu. Pohon-pohon yang ada di kawasan itu juga diakui sebagai hasil tanaman Nenek Moyang Mereka. Sehingga ada beberapa pohon yang dijadikan sebagai bukti sejarah, kenyataannya di kawasan hutan tersebut tidak ada pepohonan lebat layaknya hutan belantara juga menjadi dasar warga berbuat demikian. "kalaupun ada, hanya nangka, kopi, dan mangga yang merupakan tanaman leluhur kami.". ${ }^{14}$

Menurut $\mathrm{R}$ pengklaiman yang dilakukan oleh pengelola TNGR juga dianggap tidak mampu menunjukan tapal batas yang jelas sebagaimana yang ditetapkan pada waktu jaman Belanda, yang dijadikan dasar hukum penguasaan mereka atas tanah kawasan hutan TNGR, karena itulah sebabnya warga masyarakat berani mengklaim tanah yang luasnya puluhan hektar itu sebagai tanah leluhur kami. Sebelum ada pengesahan, semua lahan dikatakan dikuasai pejuang tanah adat. Bahkan siapapun yang memasuki kawasan tersebut haruslah atas dasar seizin kami. "hal tersebut kami lakukan

14 Sebagaimana yang dikatakan oleh $\mathrm{R}$ (pemuda yang mengaku pejuang tanah adat Jurang Koak). Wawancara Tanggal 7 Juni 2017. 
untuk menghindari ha-hal yang tidak kami inginkan.

Sedangkan menurut Syarapudin (Kepala Desa Bebidas) hanya meminta kedua belah pihak untuk menahan diri Baik pihak pengelola TNGR maupun warga masyarakat yang mengklaim diri sebagai pejuang tanah adat, karena harus menghormati bulan puasa yang sedang berlangsung pada saat konflik terjadi. Bahkan Kepala Desa katanya sudah bersurat dan tembusan ke Presiden Republik Indonesia untuk membantu menyelesaian sengketa tersebut. Oleh karena itu diminta semua pihak untuk menahan diri. ${ }^{15}$

Sedangkan menurut Ramsjah (Kepala Seksi Pengelolaan Taman Nasional Wilayah II) bahwa "Awal mula terjadinya perambahan itu sejak tanggal 14 Juni 2015 lalu, pada saat itu, puluhan warga atas komando sejumlah orang tiba-tiba masuk ke kawasan hutan. Mereka membabat beragam tanaman yang dilindungi oleh Negara."Tidak mau tinggal diam, sehari berselang pasukannnya datang dengan bersejata lengkap. Mereka menemukan banyak masyarakat yang membawa parang, menebang satu demi satu pohon yang ada disana hitung-hitungannya sektar 70 orang yang masuk ke kawasan TNGR dan membabat lahan seluas 50 hektar. Petugas yang mencoba memberi penjelasan tidak diindahkan, bahkan hingga kini perambahan masih terus dilakukan. Luasan area tersebut mulai dari tapal batas TN 468 sampai TN 472 . Yang terbaru, sekitar tanggal 18 lalu pihak kembali turun bersama polisi dan menagkap seorang warga yang berinisial ZA alias AA yang sedang melakukan perambahan. "waktu itu prosesnya sampai dimana saya kurang tahu, itu ada di polisi,".

Bahkan berita ini sudah terdengar hingga kepusat. Tidak tanggung-tanggung,

${ }^{15}$ Wawancara Tanggal 7 Juni 2017 di Kantor Desa Bebidas.
Departemen Lingkungan Hidup dan Kehutanan sedang dalam perjalanan dari Jakarta. Mereka segera melakukan tindakan pemberantasan aksi perambahan tersebut. Dalam Undang-Undang Nomor 18 Tahun 2013 terkait Pencegahan dan Pemberantasan Perusakan Hutan, masyarakat bisa dijerat dengan hukuman dari 1 sampai 3 tahun, tidak hanya itu mereka juga bisa dikenakan denda sebesar Rp. 500.000.000,00 (lima ratus juta rupiah) hingga Rp. 15 Milyar (lima belas miliyar rupiah). Apabila dilihat memang tidak bisa dibiarkan karena itu merupakan kawasan TNGR.

Penetapan kawasan TNGR sudah mengacu sejumlah aturan Negara. Tidak ada pihak manapun yang boleh melakukan pencaplokan dan mengklaim kawasan itu. Karena mediasi yang sudah berulang kali dilakukan namun terus gagal, sehingga pihak Pemerintah pada waktu itu meminta bantuan POLRES Lombok Timur untuk mensterilkan lokasi tersebut.

Pada waktu itu juga warga masyarakat di tiga Dusun yaitu Dusun Jurang Koak, Dusun Gorne, dan Dusun Tana Betiang Desa Bebidas Kecamatan Wanasabe dihimbau untuk tidak melakukan pembukaan lahan di kawasan Taman Nasional Gunung Rinjani.

Himbauan yang dikeluarkan oleh pihak Pengelola Taman Nasional Gunung Rinjani tidak diindahkan oleh warga masyarakat, hal ini tidak terlepas dari kondisi ekonomi warga masyarakat di sekitar kawasan hutan Taman Nasional Gunung Rinjani yang tergolong ekonomi lemah, dan mengantungkan hidupnya pada hasil hutan tersebut. Oleh karena itu, impliksi yang akan terjadi apabila pemerintah menutup akses warga masyarakat ke kawasan hutan Taman Nasional Gunung Rinjani adalah: terjadi kejahatan dan kriminalisasi dimana-mana karena mereka akan kehilangan mata pencarian. 
Sahnan \& Zainal Asikin|Penegakan Hukum Pemanfaatan Tanah Kawasan Hutan di Kabupaten..

Kemudian terhadap penegakan hukum yang dilakukan kepada warga masyarakat khususnya kepada Rusmin Nuryadin alias Amaq Wir (Ketua Pejuang tanah adat) dapat terlihat dimana Penuntut Umum telah melakukan dakwaan yang disusun secara alternatif. ${ }^{16}$ Alternatif pertama: Terdakwa didakwa melanggar Pasal 92 ayat (1) huruf b jo Pasal 17 ayat (2) huruf a UU Nomor: 18 tahun 2013 tentang Pencegahan dan Pemberantasan Perusakan Hutan jo Pasal 55 ayat (1) ke-1 KUHP atau Pasal 40 ayat (2) jo Pasal 33 ayat (3) UU Nomor: 5 tahun 1990 tentang konservasi Sumber Daya Alam Hayati dan Ekosistemnya jo Pasal 55 ayat (1) ke-1 KUHP. Alternatif ke-2 (kedua) dimana Terdakwa didakwa melanggar Pasal 40 ayat (2) jo Pasal 33 ayat (3) UU Nomor: 5 tahun 1990 tentang Konservasi Sumber Daya Alam Hayati dan Ekosistemnya jo Pasal 55 ayat (1) ke-1 KUHP.

Dari dakwaan penuntut umum yang disusun secara alternatif di atas, maka Majelis Hakim langsung memilih dakwaan penuntut umum yang alternatif ke-2 dengan melihat faktafakta di persidangan yaitu dakwaan yang unsur-unsurnya adalah sebagai berikut:

1. Setiap orang.

2. Dilarang melakukan kegiatan yang tidak sesuai dengan fungsi zona pemanfaatan dan zona lain taman nasional, hutan raya dan taman wisata alam.

3. Sebagai yang melakukan, menyuruh melakukan atau turut serta melakukan.

\section{Keadaan yang memberatkan}

- Perbuatan terdakwa menimbulkan kerugian bagi taman nasional gunung rinjani yaitu:

- Mengganggu ekosistem hutan tersebut;

${ }^{16}$ Putusan Pengadilan Negeri Selong Nomor: 115/ Pid Sus/2016/PN. Sel, Tahun 2016, hlm. 35-43.
- Hutan tersebut tidak dapat lagi menyimpan air ataupun bisa menyebabkan terjadinya erosi;

- Hutan tidak dapat lagi memproduksi oksigen;

- Menimbulkan kerugian Negara dari sisi ekonomi dengan adanya penebangan secara tidakbertanggung jawab serta dengan semakin sempitnya wilayah hutan akibat kegiatan perambahan.

- Terdakwa berbelit-belit dan tidak mengakui perbuatannya;

\section{Keadaan yang meringankan :}

Terdakwa bersikap sopan di persidangan dengan pertimbangan bahwa terdakwa dijatuhi pidana dan terdakwa sebelumnya tidak mengajukan permohonan pembebasan dari pembayaran biaya perkara, maka terdakwa harus dibebankan untuk membayar biaya perkara yang besarnya akan ditentukan dalam amar putusan ini;

Memperhatikan, Pasal 40 ayat (2) jo Pasal 33 ayat (3) Undangundang No. 5 Tahun 1990 tentang Konservasi Sumber Daya Alam Hayati dan Ekosistemnya jo Pasal 55 ayat (1) ke-1 KUHP, dan Undang-Undang No 8 Tahun 1981 tentang KUHAP serta peraturan perundang-undangan lain yang bersangkutan.

Dari dasar pertimbangan di atas majelis hakim memutuskan sebagai berikut:

1. Menyatakan terdakwa Rusmin Nuryadin alias Amaq Wir tersebut diatas, terbukti secara sah dan meyakinkan bersalah melakukan tindak pidana "menyuruh lakukan melakukan kegiatan yang tidak sesuai dengan fungsi zona pemanfaatan dan zona lain taman nasional," sebagaimana dalam dakwaan ke-2 penuntut umum;

2. Menjatuhkan pidana kepada terdakwa oleh karena itu dengan pidana penjara selama I (satu) tahun dan 6 (enam) bulan, serta pidana denda sebesar Rp 
50.000.000,- ( lima puluh juta rupiah ) denganketentuanapabiladendatersebut tidak dibayar maka akan diganti dengan pidanakurunganselama6 (enam) bulan;

3. Menetapkan masa penangkapan dan penahananyang telah dijalani Terdakwa dikurangkan seluruhnya dari pidana yang dijatuhkan;

4. Menetapkan Terdakwa tetap ditahan;

5. Menetapkan barang bukti berupa : 1 (satu) unit alat berat berupa excavator merk Hyundai, type R 2107, nomor register: 12, warna kuning milik PT Pramana Artha Raharja, dikembalikan kepada Penuntut Umum agar dapat dipergunakandalam perkara atas nama Terdakwa Sulaiman dan Sapi'i;

6. Membebankan kepada terdakwa untuk membayarbiayaperkarainisejumlahRp. 2.500,- (dua ribu lima ratus rupiah)

Dari gambaran di atas terlihat bahwa penegakan hukum atau pelaksanaan hukum yang dilakukan tidak bisa hanya dilihat dari sisi kepastian hukum saja. Pada hal dalam penegakan hukum harus juga memperhatikan sisi yang lain seperti sisi kemanfaatan dan keadilan. Sisi kemanfaatan, dimana didalam penegakan hukum harus memperhatikan kegunaan atau manfatnya bagi masyarakat. Jangan sampai justru karena hukumnya dilaksanakan atau ditegakkan timbul keresahan di dalam masyarakat. seperti kasus pemanfaatan tanah kawasan hutan TNGR, dimana terhadap pemanfatan tanah kawasan hutan tersebut telah menimbulkan keresahan, bahkan telah terjadi konflik atau sengketa antara warga masyarakat Dusun Jurang Koak Desa Bebidas, Kecamatan Wanasaba, Kabupaten Lombok Timur dengan Pihak Pengelola TNGR atau pemerintah. Sedangkan dari sisi keadilan, dimana penegakan hukum kepada masyarakat khususnya warga masyarakat Dusun Jurang Koak Desa Bebidas sangatlah mereka harapkan. Dalam penegakan hukum harus adil. Hukum tidak identik dengan keadilan. Hukum itu bersifat umum, mengikat kepada semua orang, bersifat menyamaratakan. Sebaliknya keadilan bersifat subyektif, individualis dan tidak menyamaratakan. Adil bagi Pemerintah atau Penggelola TNGR belum tentu adil bagi warga masyarakat. ${ }^{17}$

Dalam penegakan hukum tidak bisa hanya memperhatikan salah satu dari ketiga unsur yang ada. Dalam penegakan hukum harus ada kompromi antara ketiga unsur-unsur tersebut. Ketiga unsur itu harus mendapatkan perhatian secara proporsional seimbang. Akan tetapi didalam praktik tidaklah mudah mengusahakan kompromi secara proporsionalantaraketiga unsur tersebut. ${ }^{18}$

Faktor-faktor yang menjadi kendala dalam penegakan hukum pemanfaatan tanah kawasan hutan di Dusun Jurang Koak, Desa Bebidas, Kecamatan Wanasaba, Kabupaten Lombok Timur.

Hampir semua bidang kehidupan dewasa ini telah diatur oleh hukum, dan sulit ditemukan suatu bidang tertentu dalam kehidupan masyarakat yang tidak tersentuh dengan hukum. Campur tangan hukum yang semakin meluas ke dalam kehidupan masyarakat menyebabkan masalah efektifitas penerapan hukum menjadi semakin penting untuk diperhitungkan. Itu artinya hukum harus bisa menjadi institusi yang bekerja secara efektif di dalam masyarakat. ${ }^{19}$

Kalaupun hukum dalam tataran normatif telah berusaha untuk memberikan jaminan kepercayaan pada masyarakat, namun dalam tataran empiris, bekerjanya hukum untuk mewujudkan fungsinya sebagai sarana penyelesaian sengketa ternyata tidak semudah yang

\footnotetext{
${ }^{17}$ Sudikno Mertokusumo, Mengenal Hukum Sebagai Suatu Pengantar,Liberty, Yogyakarta, 2003, hlm. 160-

${ }^{18}$ Ibid.

${ }^{19}$ Menurut pendapat Esmi Warassih sebagaimana dikutip oleh Sahnan, Hukum Agraria Indonesia, Setara Press, Malang, 2016, hlm: 91.
} 161. 
Sahnan \& Zainal Asikin|Penegakan Hukum Pemanfaatan Tanah Kawasan Hutan di Kabupaten..

dibanyangkan. Hukum tidak berada di ruang hampa, akan tetapi hukum masih dipengaruhi oleh faktor-faktor di luar hukum seperti politik, ekonomi, dan sosial budaya lainnya. ${ }^{20}$

Keterbatasan kemampuan hukum untuk menjalankan fungsinya dalam masyarakat disebabkan kehadiran hukum bukan berwujud sebagai suatu benda mati ataupun robot komputer yang diprogramkan untuk menetralisir segala rintangan yang timbul dan mewujudkan tugasnya. ${ }^{21}$ Akan tetapi pihak yang mewakili untuk menjalankan hukum untuk menyelesaikan dan menjalankan tugas menyelesaikan sengketa atas nama hukum adalah manusia, yang notabena banyak memiliki keterbatasan dalam menjalankan aktifitasnya. ${ }^{22}$

Dari pandangan di atas apabila di pertalikan dengan teori penegakan hukum dari L. Friedmans maka dapat ditarik suatu pemahaman bahwa yang menjadi faktor kendala dalam penegakan hukum dalam pemanfaatan tanah kawasan hutan khususnya tanah kawasan hutan Dusun Jurang Koak Desa Bebidas adalah:

1. Faktor Struktur

Penegakan hukum sangat dipengaruhi oleh sumberdaya manusia dan perilaku aparat penegaknya seperti: Polisi, Jaksa, dan Hakim. Para penegak hukum cenderung menafsirkan hukum sesuai kepentingan para penguasa atau pihak-pihak yang mampu membeli hukum.Ewuhpakewuhdalampenegakan hukumsudahtidakasinglagi.Olehkarena itu dapat dikatakan bahwa penegakan hukum sangat tergantung prilaku aparatnya penegak hukumnya. Jika aparatpenegaknyabaik makahukumnya akan baik, namun sebaliknya apabila aparat penegaknya tidak baik maka hukumnya tidak baik.

2. Faktor Substansi

\footnotetext{
${ }^{20}$ Ibid. hlm. 4.

${ }^{21}$ Pendapat Adi sulistiyono sebagaimana dikutip oleh Sahnan, Ibid.hlm 4

22 Ibid. hlm. 5
}

Jika dilihat dari faktor substansi yang menjadi kendala dalam penegakan hukum khususnya dalam kaitan pemanfaatan lahan atau tanah kawasan hutan, keberadaan masyarakat adat, dan kewenangan secara adminstrasi adalah masihterjaditumpangtindihpengaturan antara undang-undang yang satu dengan yang lainnya, sebagai misal masalah masyarakat adat selain diatur di dalam Undang-Undang nomor 5 tahun 1960 tentang Peraturan Dasar Pokok-Pokok Agraria, juga diatur di dalam UndangUndang kehutanan dan atau di UndangUndang mengenai Hak Asasi Manusia. Begitu juga masalah kewenangan pemanfaatan tanah kawasan hutan juga terjadi dualisme kewenangan sebagai misal: tanah kawasan hutan. Masalah tanahnya menjadi kewenangan Badan Pertanahan Nasional Dan Tata Ruang, sedangkan masalah hutannya menjadi kewenangan Kementerian Kehutanan dan Lingkungan Hidup. Dari dualisme kewenangan administrasi tersebut telah berdampak kepada munculnya konflik atau sengketa kewenangan mengenai penguasaan atau pemanfaatan tanah kawasan hutan seperti tanah kawasan hutan Taman Nasional Gunung Rinjani.

3. Faktor Kultur Hukum

Dalam penegakan hukum atau menyelesaikan masalah masyarakat adat. Para penegak hukum harus mampu memahaminilai-nilaibudayayanghidup dalam masyarakat setempat. Karena dalam masyarakat adat penyelesaian masalah atau penegakan hukum, hanya mereka yakini menurut pemahaman nilai-nilai budaya yang hidup selama ini di tengah ke hidupan mereka, dan itulah yang mereka anggap adil.

Untuk menyelesaikan masalah penguasaan tanah dikawasan hutan pemerintah telah mengeluarkan Perpres nomor 88 tahun 2017 mengenai penyelesaian penguasaan tanah dalam kawasan hutan (PPTKH). Aturan 
ini dikeluarkan atas dasar tingginya angka permasalahan yang terjadi dalam kawasan hutan untuk fungsi lindung, konservasi, dan produksi. ${ }^{23}$ Adapun jenispenguasaanyangdapatdiselesaikan berdasarkan Perpres ini adalah: Area permukiman, fasilitas umum, dan fasilitas sosial, lahan garapan, dan hutan yang dikelola masyarakat adat. Sedangkan untuk model penyelesaian bidang tanah yang dikuasai dan dimanfaatkan setelah tanah tersebut ditunjuk sebagai kawasan hutan adalah:

1. Mengeluarkan bidang tanah dalam kawasan hutan melalui perubahan batas kawasan hutan;

2. Tukar menukar kawasan hutan;

3. Memberikanakses pengelolaanhutan melalui program perhutanan sosial;

4. Melakukanresettlement (pemindahan penduduk darikawasan hutan keluar kawasan hutan.

\section{SIMPULAN}

Pelaksanaan penegakan hukum dalam pemanfaatan tanah kawasan hutan di Dusun Jurang Koak, Desa Bebidas, Kecamatan Wanasaba, Kabupaten Lombok Timur masih belum berjalan sebagaimana yang diharapkan, di mana para aparat penegak hukum dalam penegakan hukum hanya melihat dari sisi kepastian dengan mengabaikan sisi manfaat dan keadilannya, padahal ketiga unsur tersebut harus dilaksanakan secara bersamaan, dan tidak bisa salah satu dari ketiganya dilaksanakan, kalaupun pelaksanaan dari ketiga unsur tersebut di dalam prakteknya tidaklah mudah.

Kendala-kendala yang dihadapi dalam penegakan hukum pemanfaatan tanah kawasan hutan dapat dibagi menjadi tiga yakni: dari sisi struktur, substansi dan kultur. Dari sisi struktur,

23 Erwan Hermawan (Tim Asisten Kementerian Koordinator Bidang Prekonomian), Implementasi Peraturan Presiden Nomor 88 Tahun 2017 Tentang PenyelesaianPenguasaan Tanah Dalam Kawasan Hutan (PPTKH), Lombok Post, Rabu, 29 November 2017. di mana para penegak hukum telah menjadi corong Undang-Undang dan lebih melihat dari sisi kepastian hukum dengan mengabaikan aspek keadilan dan kemanfaatan. Dari sisi substansi hukum, terlihat bahwa aturan yang mengatur mengenai tanah kawasan hutan telah terjadi tumpah tindih pengaturan antara aturan satu dengan aturan yang lain. Dan dari sisi kultur budaya hukum, di mana para penegak hukum belum mampu memahami nilai-nilai buadaya yang hidup dalam masyarakat setempat. Begitu juga menurut persepsi masyarakat bahwa Penyelesaian masalah atau penegakan hukum pemanfaatan tanah kawasan hutan, hanya mereka yakini menurut pemahaman nilai-nilai budaya yang hidup selama ini di tengah ke hidupan mereka.

\section{DAFTAR PUSTAKA}

\section{Buku}

Atmosudirdjo, 1981, Prajudi, Hukum Administrasi Negara, Ghalia Indonesia, Jakarta.

Bambang Eko Supriyadi, 2013, Hukum Agraria Kehutanan: Aspek Hukum Kehtanan Dalam Pengelolaan Hutan Negara, Raja Grafindo Persada, Jakarta,.

Fifik Wiryani, 2009, Reformasi Hak Ulayat, Pengaturan Hak-hak Masyarakat Adat dalam Pengelolaan Sumber daya Alam, Setara Press, Malang.

Lawrence Friedmann, 2011, Sistem Hukum: Perspektif Ilmu Sosial, Nusa Media, Bandung.

Risdiana, 2017, Perlindungan Hukum Hak Atas Tanah Hutan yang Dikelola Masyarakat Adat Dalam Kawasan Hutan Tamanan Nasional Gunung Rinjani, Dusun Jurang Koak, Desa Bebidas, Kecamatan Wanasaba, Kabupaten Lombok Timur,Program Magister Ilmu Hukum, Program Pascasarjana, 
Sahnan \& Zainal Asikin|Penegakan Hukum Pemanfaatan Tanah Kawasan Hutan di Kabupaten..

Universitas Mataram.

Sahnan, Pilihan Hukum Penyelesaian

Sengketa Di Luar Pengadilan

(Studi Kasus Sengketa Tanah

Hak Guna Bangunan (HGB)

PT. Sinar Rowok Indah Di

Kawasan Pariwisata Selong

Belanak, Kabupaten Lombok

Tengah, Provinsi Nusa Tenggara

Barat), Disertasi Program Doktor

Ilmu Hukum Fakultas Hukum

Universitas Brawijaya, Malang,

Tahun 2010.

2016, Hukum Agraria Indonesia,

Setara Press, Malang.

et.al, 2016, Sengketa Pemanfaatan

Tanah Kawasan Hutan Antara

Warga Masyarakat Dengan Dinas

Kehutanan (Studi Kasus Tanah

Kawasan Hutan Pelangan, Desa

Kedaro, Kec. Sekotong, Kab.

LombokBarat, NTB.

Sudikno Mertokusumo, 2003, Mengenal Hukum Sebagai Suatu Pengantar, Liberty, Yogyakarta.

\section{Jurnal}

M. Yazid Fathoni, Konsep Keadilan Dalam Pengelolaan dan Pemanfaatan Sumber Daya Alam Menurut Undang-Undang Pokok Agraria Tahun 1960, Jurnal IUS (Hukum dan Keadilan), 1. 1 (2013), http:// jurnalius.ac.id/ojs/index.php/ jurnalIUS/article/view/225/197, diakse tanggal 6 Januari 2017

\section{Peraturan Perundang-Undangan}

Undang Undang Dasar Negara Republik Indonesia Tahun 1945,

Undang-Undang Nomor 5 tahun 1960 tentang Peraturan Dasar Pokokpokok Agraria, Lembaran Negara Tahun 1960 Nomor 104-Tambahan Lembaran Negara Nomor 2043.
Undang-Undang Nomor 41 Tahun 1999 tentang Kehutanan.

Peraturan Bersama Menteri Dalam Negeri Indonesia, Menteri Kehutanan Republik Indonesia, Menteri Pekerjaan umum Republik Indonesia dan Kepala Badan Pertanahan Nasional Republik Indonesia Nomor: 79 Tahun 2014, Nomor: PB.3/Menhut-11/2014, Nomor : 17/PRT/M/2014, Nomor: 8/SKB/X/2014 tentang Tata Cara Penyelesaian Penguasaan Tanah yang berada di Kawasan Hutan.

\section{Media Cetak dan lain-lain.}

Berkas Perkara Nomor: BP 03/V/ B T N G R - 1 / P P N S / 2016 Kementrian Lingkungan Hidup dan Kehutanan Direktorat Jenderal Konservasi Sumber Daya Alam dan Ekosistem Balai Taman Nasional Gunung Rinjani.

Putusan Pengadilan Negeri Selong Nomor: 115/Pid Sus/2016/PN. Sel, Tahun 2016.

Erwan Hermawan (Tim Asisten Kementerian Koordinator Bidang Prekonomian), Implementasi Peraturan Presiden Nomor 88Tahun $2017 \quad$ Tentang PenyelesaianPenguasaan Tanah Dalam Kawasan Hutan (PPTKH), Lombok Post, Rabu, 29 November 2017. 